\title{
低密度調整剂添加によるリサイクルシートの特性変化
}

\author{
金 海蘭 ${ }^{* 1} \cdot$ 渡辺 光正 ${ }^{* 2} \cdot$ 大谷 肇*3 $\cdot$ 李 堅*1 $\cdot$ 岡山 隆之*2,
}

\section{Effects of Internal Addition of Bulking Agents on Properties of Recycled Handsheet}

\author{
Hailan Jin $^{* 1}$, Kosei Watanabe ${ }^{* 2}$, Hajime Ohtani ${ }^{* 3}$, Jian Li $^{* 1}$, and Takayuki Okayama ${ }^{* 2, \#}$ \\ ${ }^{* 1}$ Key Lab of Bio-based Material Science and Technology of Ministry of Education, Northeast Forestry \\ University, No.26 Hexing Road, Xiangfang District, Harbin 150040, China \\ ${ }^{* 2}$ Graduate School of Agriculture, Tokyo University of Agriculture and Technology, 3-5-8 Saiwai-cho, \\ Fuchu, Tokyo 183-8509, Japan \\ ${ }^{* 3}$ Department of Materials Science and Engineering, Graduate School of Engineering, Nagoya Institute of \\ Technology, Nagoya 466-8555, Japan
}

\begin{abstract}
In this study, the effect of adding bulking agents on properties of recycled handsheet, and sizing performance was evaluated. The density of handsheet decreased with recycling, and the addition of bulking agents further reduced it. Repeated recycling increased the total pore volumes, and the addition of bulking agents further increased it. In any case, the addition of the bulking agents contributed to the AKD retention. The addition of one of the bulking agents improved the sizing performance further only AKD on recycled handsheet. In the case of recycling 5 times, the ratio of the pore diameter region ranting from 4 to $8 \mu \mathrm{m}$, it was confirmed that the increase of pore volume by addition of the bulking agents.
\end{abstract}

(Received 11 January, 2015 ; Accepted 6 March, 2015)

\section{1. 緒 言}

近年, 地球環境保護の観点から省資源, 省エネルギー を志向する低密度化紙と呼ばれる紙の生産量が増加して いる.これは, 普通紙と比較して同じ紙厚でありながら 軽量な紙, すなわち密度の低い紙のことである. その低 密度化の手法として, 紙料に低密度調整剂を添加する方 法がよく用いられ[1,2], 低密度調整剤の添加による紙の 厚さの向上もこれまでの研究で確認されてきた $[3,4]$.

原料への古紙の利用は, コスト削減, パルプ原料の節 約, 国内外の森林資源の温存, また廃衰物の発生抑制に よる自治体のゴミ収集・処理の負担軽減に結びつき, 経 済的に有利であるばかりでなく, 環境・資源問題への寄 与も大きい. 低密度調整剤を利用した低密度化紙の使 用 量の増加に伴い, 古紙の利用も増加するものと考えられ る. しかし低密度調整剂の添加による再生紙の物理的性 質への影響はまだ明らかになっていない. そのため, 低 密度調整剂添加による低密度化リサイクル紙の特性変化 を検討することは重要であると考えられる。

\# corresponding author

*1 東北林業大学生物質材料科学技術教育部重点実験室

*2 東京農工大学大学院農学府 E-mail:okayama@cc.tuat.ac.jp

*3 名古屋工業大学大学院工学研究科
従って, 本研究ではリサイクルシートの特性に及ぼす 低密度調整剂添加の影響およびサイズ性に及ぼす影響に ついて研究を行った.

\section{2. 実 験}

\section{1 試 料}

パルプは, 針葉樹漂白クラフトパルプ(NBKP)を用い, 低密度調整剤は自己サイズ性を有するステアリン酸アミ ドアミン系低密度調整剤(低密度調整剤 A) と自己サイズ 性のないオレイン酸アミドアミン系低密度調整剂(低密度 調整剂 B)の 2 種を実験に用いた（Table 1)。また，製紙技 術における酸性から中性への決定的な変化を経て, アル キルケテンダイマー $(\mathrm{AKD})$ が中性サイズ剤として頻繁に 使用されているため, サイズ剤は中性サイズ剤 $\mathrm{AKD}$ (荒 川化学工業社製 K-903-20)を用いた。

\section{2 低密度化リサイクル紙の作製}

吒解した NBKP に乾燥・湿潤のリサイクル処理を行い, JIS P8222 に準じて坪量 $60 \pm 3 \mathrm{~g} / \mathrm{m}^{2}$ のリサイクル回数 0,1 , 5 回(R0, R1, R5 と略す)のリサイクルパルプ繊維シート を作製した。いずれのパルプに対しても, 低密度調整剤 $\mathrm{A}, \mathrm{B}(0.8 \mathrm{wt} \%)$ を添加し，リサイクル手すきシートを作製 した.

また,リサイクルパルプに対し, 低密度調整剂 A, B 
(0.8wt\%) および $\mathrm{AKD}(0.1 \mathrm{wt} \%)$ を併用した手すきシートを 作製した。すべての試験用シートの乾燥条件は，比較評 価のため同様に $105^{\circ} \mathrm{C}, 10$ 分間の送風乾燥を行った. 作 製した試験用手すきシートは $23^{\circ} \mathrm{C} ， 50 \%$ R.H.にて調湿後, 測定に用いた.

\section{3 シートの物理的諸特性の測定}

手すきシートはJIS に従い, 密度のほか, 引張強さ, ゼ ロスパン引張強さなどの物理的諸特性の測定を行った.

シートのサイズ度測定はステキヒトサイズ度試験 (Stöckigt sizing test)に準じた [5]. 低密度調整荗の添加によるシー ト纎維間結合力の評価は, 前の論文[2]と同じく Page の 式を[9]を用いて検討した。すずての実験データは繰り返 し 10 回の平均值を用いた.

\subsection{AKD 歩留まりの測定}

シート中の AKD 歩留まりは約 $1 \mathrm{mg}$ のシートに対し, 熱分解ガスクロマトグラフィー $(\mathrm{Py}-\mathrm{GC})$ によって定量した [6,7]. ガスクロマトグラフによる定量には GC 4000 (GL サイエンス(株), 熱分解装置は Frontier Lab PY-2010SL を 用いた. 熱分解温度は $500^{\circ} \mathrm{C}, \mathrm{GC}$ オーブン温度は $50^{\circ} \mathrm{C}$ から $300^{\circ} \mathrm{C}$ まで毎分 $15^{\circ} \mathrm{C}$ の昇温操作を行った. 分離カラ ムには Frontier Lab Ultra ALLOY ${ }^{+}-5$ (5\% diphenyl, 95\% dimethyl polysiloxane, $30 \mathrm{~m}$ x $0.25 \mathrm{~mm}$ i.d., $0.25 \mu \mathrm{m}$ film)を使 用し, 水素炎イオン化検出器にて検出・記録した. シー ト中の AKD 含有量はパイログラム上の観測される当該成 分のピーク面積に基づいて評価した.

\section{5 水銀圧入法によるシート空隙構造の測定}

シートの細孔分布測定には水銀圧入法に従い [8], 水銀 ポロシメーター（Micromertics Pore Size 9310）(島津製作所） 装置を用いた.

水銀ポロシメーターは真空から $206.85 \mathrm{~Pa}$ に及ぶ圧力範 囲での水銀圧入量の変化が測定可能である. 本測定では, 低圧領域 (大気圧 $0.1034 \mathrm{~Pa}$ 以下) で試験片の重なりによる 間隙が測定值に影響を与えることを考え, 測定圧力 $15 \mathrm{psia}$ 以上のデータを採用した。

\section{3. 結果及び考察}

\section{1 リサイクル繊維シートの物性に及ぼす低密度調 整剤添加の影響}

Fig. 1 には, 低密度調整剂の添加によるリサイクル繊維 シート密度の変化を示す.いずれの場合もリサイクル回 数の増加に伴いシートの密度は低下する傾向にあった. 一般に, リサイクルによる密度の低下は湿潤・乾燥の繰 り返しにより生じる繊維の不可逆的変化のため, 䋊維間 結合能力の低下および繊維の膨潤性低下によるコン フォーマビリティの低下が原因であると考えられる，低 密度調整剂の添加はリサイクルによるシート密度低下の 傾向を維持しながら，より低い密度をもたらすことから， リサイクルパルプにおいても低密度化効果は有効である と判断した．また，単独あるいは AKD との併用いずれの 場合も低密度調整剤 A より B の低密度化効果がわずかに

Table 1 Properties of bulking agents.

\begin{tabular}{cccccc}
\hline & $\begin{array}{c}\text { Type of } \\
\text { fatty acid amide amine }\end{array}$ & $\begin{array}{c}\text { Melting point } \\
\left({ }^{\circ} \mathrm{C}\right)\end{array}$ & $\begin{array}{c}\mathrm{pH} \\
(0.5 \%)\end{array}$ & $\begin{array}{c}\text { Surface tension } \\
(0.1 \%)(\mathrm{Nm} / \mathrm{m})\end{array}$ & $\begin{array}{c}\text { Particle size } \\
(\mu \mathrm{m})\end{array}$ \\
\hline A & Stearic acid & 78 & 6.6 & 62 & 4.77 \\
$\mathrm{~B}$ & Oleic acid & 42 & 6.6 & 28.4 & 7.1 \\
\hline
\end{tabular}

Table 2 Properties of recycled handsheet with internal addition of bulking agents with AKD.

\begin{tabular}{|c|c|c|c|c|c|c|}
\hline & Recycling & Density & $\begin{array}{l}\text { Tensile } \\
\text { index }\end{array}$ & $\begin{array}{c}\text { Zero-span } \\
\text { tensile index }\end{array}$ & $1 / \mathrm{B}$ & $1 / \mathrm{F}$ \\
\hline & (times) & $\left(\mathrm{g} / \mathrm{cm}^{3}\right)$ & $(\mathrm{Nm} / \mathrm{g})$ & $(\mathrm{Nm} / \mathrm{g})$ & $\mathrm{x} 10^{-2}$ & $\times 10^{-2}$ \\
\hline \multirow{3}{*}{ AKD } & 0 & 0.706 & 50.6 & 106.1 & 1.061 & 0.915 \\
\hline & 1 & 0.597 & 33.4 & 100.6 & 1.118 & 1.876 \\
\hline & 5 & 0.573 & 27.3 & 98.9 & 1.137 & 2.524 \\
\hline \multirow{3}{*}{$\mathrm{A}+\mathrm{AKD}$} & 0 & 0.673 & 35.3 & 97.0 & 1.159 & 1.676 \\
\hline & 1 & 0.607 & 21.4 & 86.5 & 1.300 & 3.382 \\
\hline & 5 & 0.544 & 16.3 & 85.0 & 1.323 & 4.814 \\
\hline \multirow{3}{*}{$\mathrm{B}+\mathrm{AKD}$} & 0 & 0.626 & 29.9 & 93.5 & 1.203 & 2.143 \\
\hline & 1 & 0.596 & 21.3 & 88.8 & 1.267 & 3.437 \\
\hline & 5 & 0.500 & 12.6 & 85.2 & 1.321 & 6.638 \\
\hline
\end{tabular}




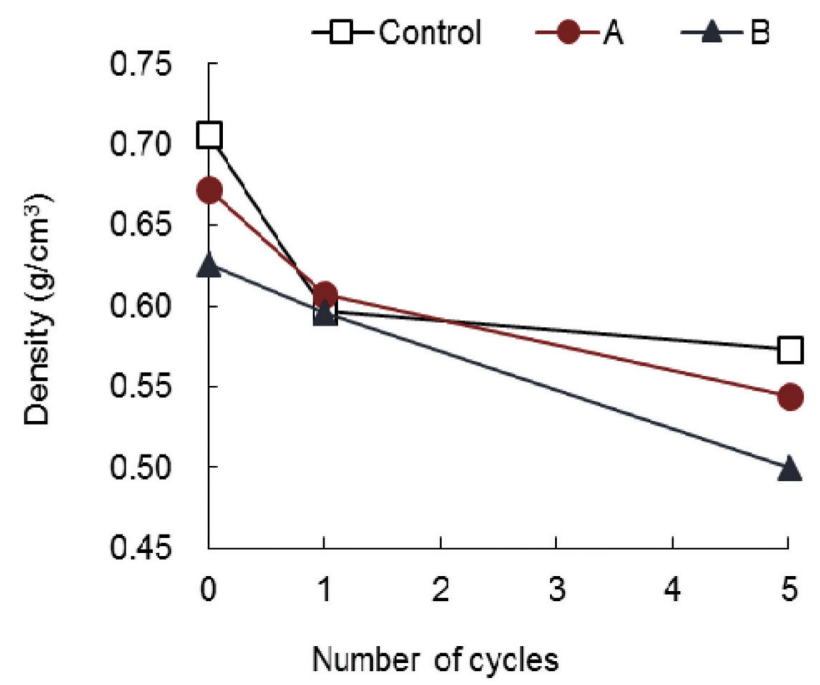

Fig. 1 Effects of addition of bulking agents on recycled handsheet density.

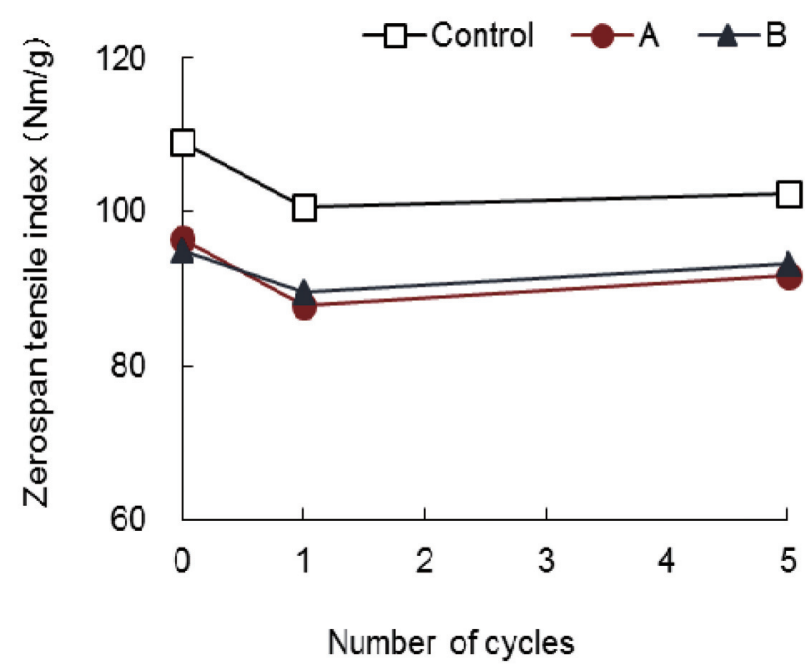

Fig. 3 Effects of addition of bulking agents on recycled handsheet zero-span tensile index.

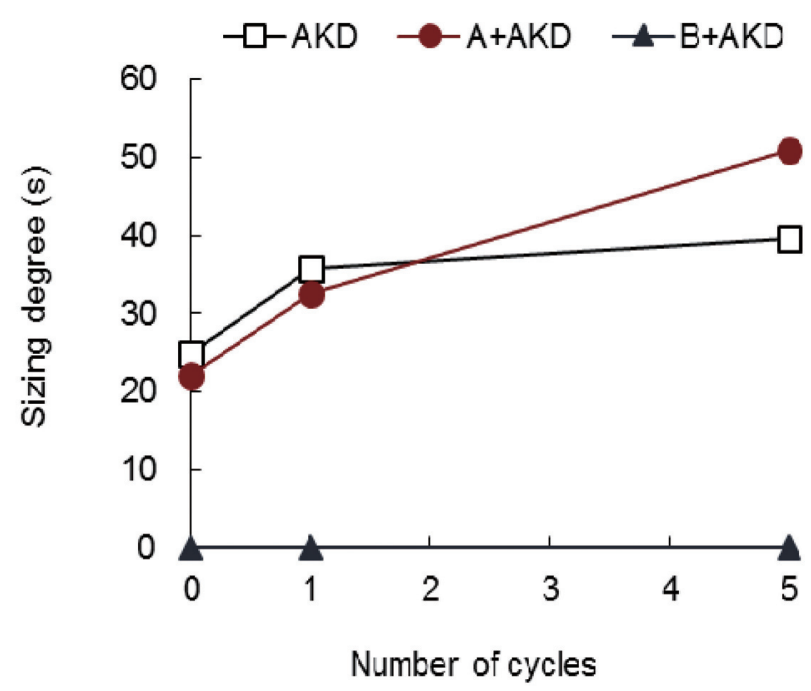

Fig. 5 Effects of AKD addition on recycled handsheet Stöckigt sizing degree.

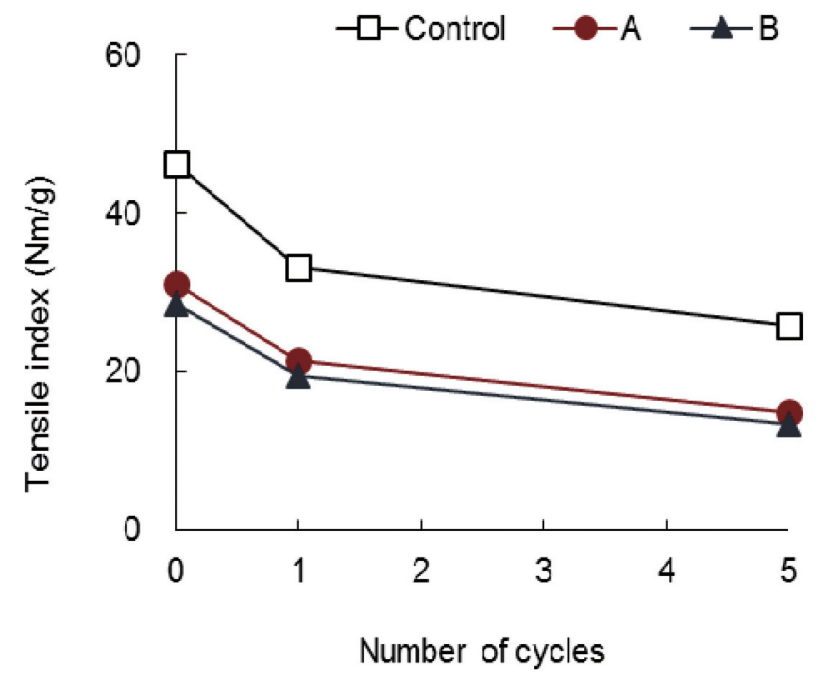

Fig. 2 Effects of addition of bulking agents on recycled handsheet tensile index.

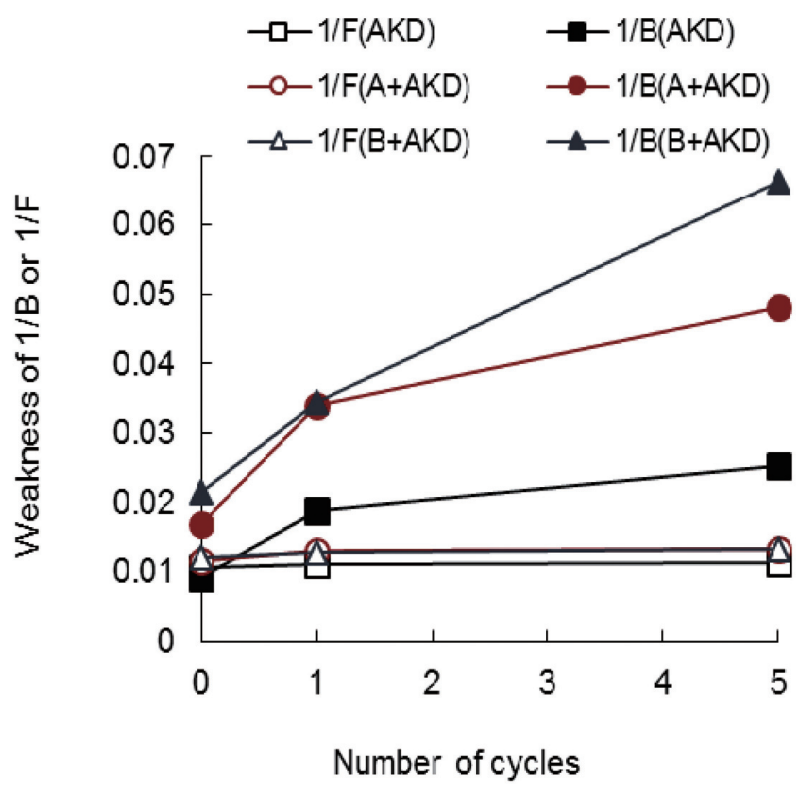

Fig. 4 Effects of addition of bulking agents on bonding and fiber weakness.

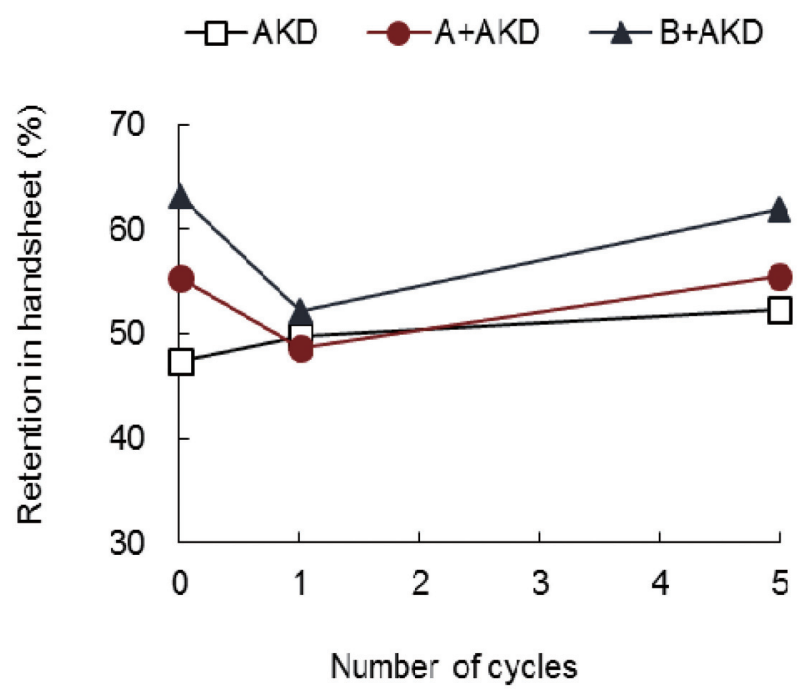

Fig. 6 AKD contents of recycled handsheet determined by Py-GC. 
良好であることが明らかとなった(Fig. 1, Table 2).

リサイクルに伴ってシートの比引張強さおよびゼロス パン比引張強さも低下する傾向にあった（Fig. 2，3).

シートの引張強さに影響する要因の関係を提案したも のに, Page の式[9]がある.さらに, Cildirらは次の Page の式を応用して, 破断に対する抵抗力はこれに匹敵する 二つの抵抗力からなるという視点から繊維間結合力の評 価を提案した[10].

$$
\frac{1}{T}=\frac{1}{F}+\frac{1}{B}
$$

$\mathrm{F}$ : 繊維強度指数

$\mathrm{B}$ : 結合強度指数

ここで, $\mathrm{F}=8 \mathrm{Z} / 9$ のため, 引張強さ $\mathrm{T}$ とゼロスパン引張 強さ $\mathrm{Z}$ を測定すれば, 結合強度指数 $\mathrm{B}$ が求められる.

Fig. 4 には,リサイクル繊維シートの繊維強度及び結合 強度に及ぼす低密度調整剂添加の影響を示す。いずれの 場合も繊維強度 $(1 / \mathrm{F})$ はリサイクル回数の増加によってほ とんど変化しなかったが, 結合強度 $(1 / \mathrm{B})$ が増加したこと から、リサイクルによるパルプ繊維シートの強度低下は 繊維間結合力の低下によると判断した．また，無添加の 場合リサイクル回数増加に伴うシート強度の低下は繊維 間結合力の低下によるもので, 低密度調整剤の添加によ りさらに繊維間結合力を低下させたことが明らかとなっ た.

\section{2 リイクル繊維シートのサイズ性に及ぼす低密 度調整剂添加の影響}

リサイクルパルプに AKD を単独で $0.1 \mathrm{wt} \%$ 添加した場 合, リサイクル回数の増加に伴いシートのサイズ性は向 上した(Fig. 5)。低密度調整剤 A に AKD を併用した場合, $\mathrm{AKD}$ 単独添加試料に比べてやや低い值を示すものの, AKD のサイズ性を妨害することなく高いサイズ性を維持 できることが明らかとなった．特に，R5の場合，低密度 調整剂 $\mathrm{A}$ に $\mathrm{AKD}$ を併用するとシートのサイズ度は $50 \mathrm{~s}$ 前

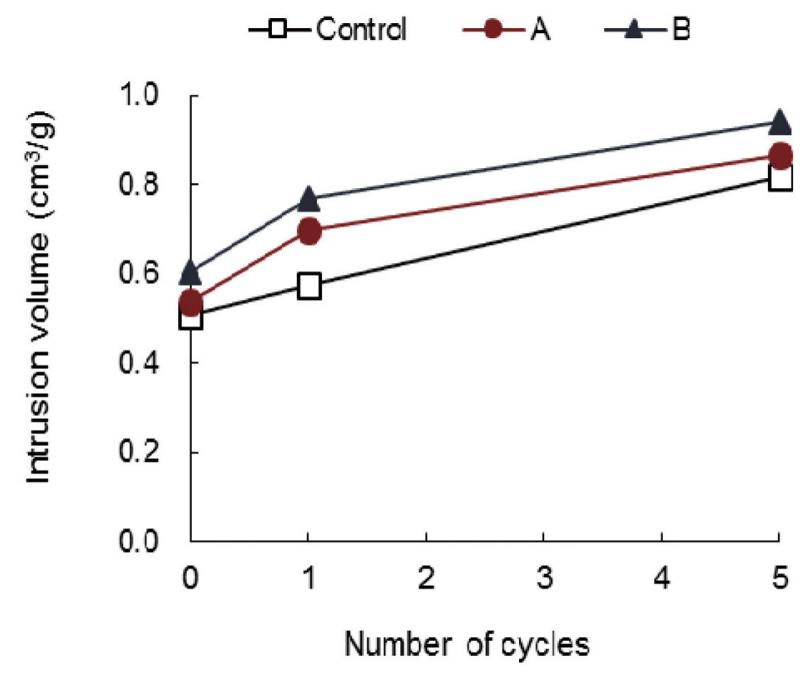

Fig. 7 Effects of addition of bulking agents on total pore volume of recycled handsheet determined by mercury porosimetry.
後まで上昇し, $\mathrm{AKD}$ 単独添加の 39s 前後より高いサイズ 度を示すことが判明した，一方，低密度調整剤 B の場合 は, シート中の含有量が A とほぼ同様であるにも関わら ず(Fig. 6), いずれの場合もサイズ性を示さないことから AKD のサイズ効果は妨害されたと推測した。

\section{3 水銀ポロシメーターによるシートの空隙構造}

水銀圧入法によるシートの全細孔容積を Fig. 7 に示す. リサイクルによりシートの細孔容積は増加の傾向にあり, 低密度調整剤の添加によってさらに増加することが確認 された。これは低密度化および繊維間結合力の低下と一 致する結果である.
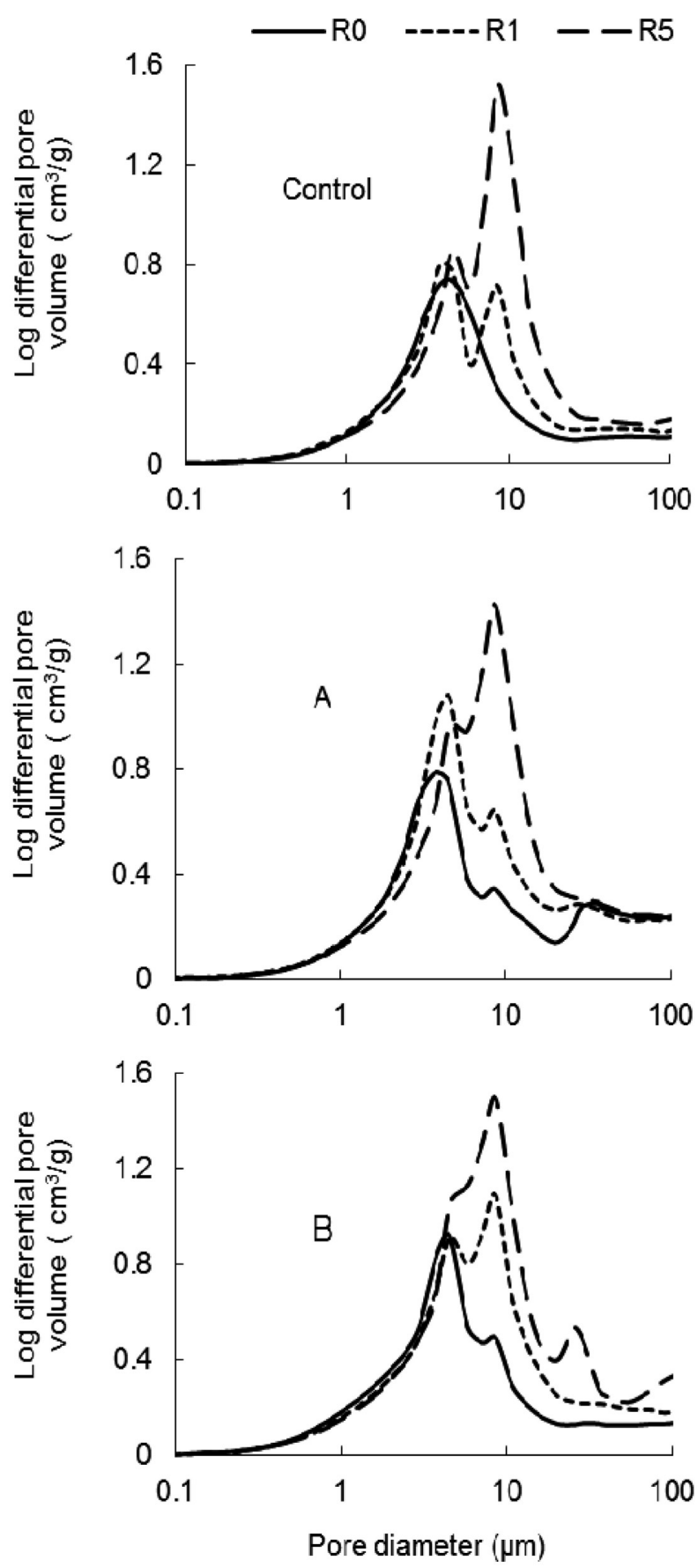

Fig. 8 Effects of addition of bulking agents on pore diameter of recycled handsheet determined by mercury porosimetry. 
いずれの試料においても, シートの細孔直径の大半が 1 〜20 $2 \mathrm{~m}$ の範囲に分布していることが確認された(Fig. 8). 低圧側に当たる細孔直径 $20 \mu \mathrm{m}$ 以上の部分は, 試料表面の くぼみ及び試料の重なり合いによる空隙への水銀の圧入 であり [11], ここで考察の対象としている密度や空隙と は関係しないため検討しない. 無添加 R0 シートの細孔直 径ピークは 1 〜 $10 \mu \mathrm{m}$ 範囲にあったが, A, B 添加シート の R0 シートはより狭い分布に, やや鋭いピークを示し, $10 \mu \mathrm{m}$ 付近で 2 つ分離する傾向にあることが確認された リサイクル回数を増加すると, 無添加シートでも 2 つの ピークに分離し, 細孔直径ピークがより大きい方へシフ トすることが明らかとなった. 同様に, R1でも同じ傾向 を示した. R5 シートの場合, 細孔直径は 2 つに分かれた ものの, 無添加シートの主なピークは $10 \mu \mathrm{m}$ にあることが 確認された。すなわち, 無添加の場合, 最初(R0)の細孔 直径ピークは4〜8 4 m であるものの, R5になると主に $10 \mu \mathrm{m}$ 付近の空隙が増加したことから, リサイクルによる 細孔容積の増加は主に $10 \mu \mathrm{m}$, この領域における細孔の増 加によるものであると判断される. ところが, 低密度調 整剂添加シートの場合, 細孔直径分布は $4 \sim 10 \mu \mathrm{m}$ にて幅 広く分布し, 特に 4 $8 \mu \mathrm{m}$ 範囲において無添加より高い ピークを示すことから, 低密度調整剤の添加によるシー ト細孔の増加は, 主としてこの領域の空隙が増加するも のと判断された.

\subsection{SEM によるシート断面の観察}

SEM によるシートの横断面観察 (Fig. 9)から, リサイク ル回数の増加に伴って紙厚が増加することが確認された. また, 低密度調整剤の添加によってさらに紙厚が増加す ることも確認された. R0, R1 試料の場合, 低密度調整剂 の添加による厚みの増加はわずかであったが, R5 の試料 ではより明らかな厚さ増加が確認できた。

\section{4. 結 論}

湿潤・乾燥によるリサイクル処理を $0,1 ， 5$ 回行った パルプに低密度調整荗を対パルプ $0.8 \% \mathrm{wt}, \mathrm{AKD}$ を対パル プ 0.1\%wt で添加した手すきシートについて, 低密度調整 剤添加によるリサイクル繊維シートの特性変化を検討し た.

1.リサイクルパルプに低密度調整剤を添加すると, い ずれの場合も低密度化効果を認め, リサイクル回数 の増加に伴ってシート密度はさらに低下する傾向に あった．低密度化に伴ってシートの引張強さが低下 したが, 繊維間結合力の低下が主な要因であること が確認された。

2. $\mathrm{AKD}$ 単独添加の場合, シートのサイズ性はリサイク ル回数増加に伴い向上する傾向にあった. また，低 密度調整剂 A R AKD を併用するとサイズ性を妨害
R0
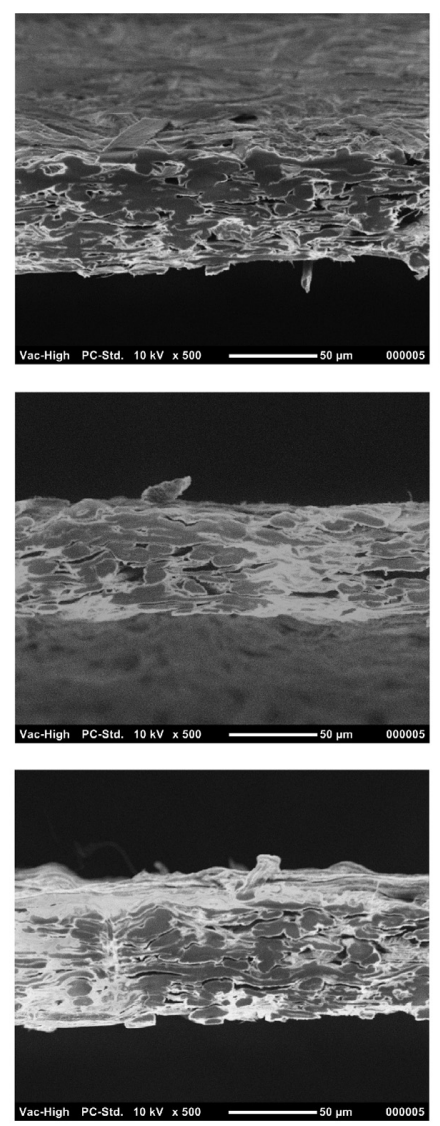

R1
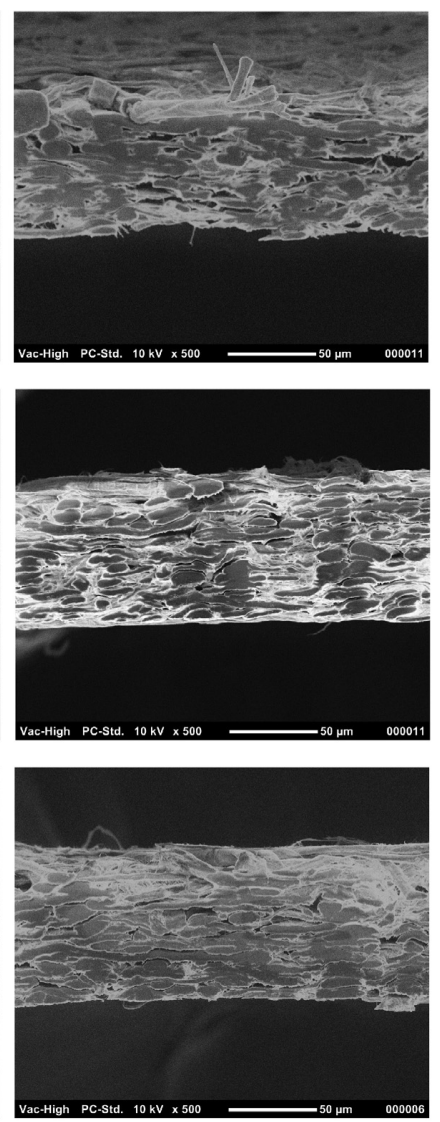

R5
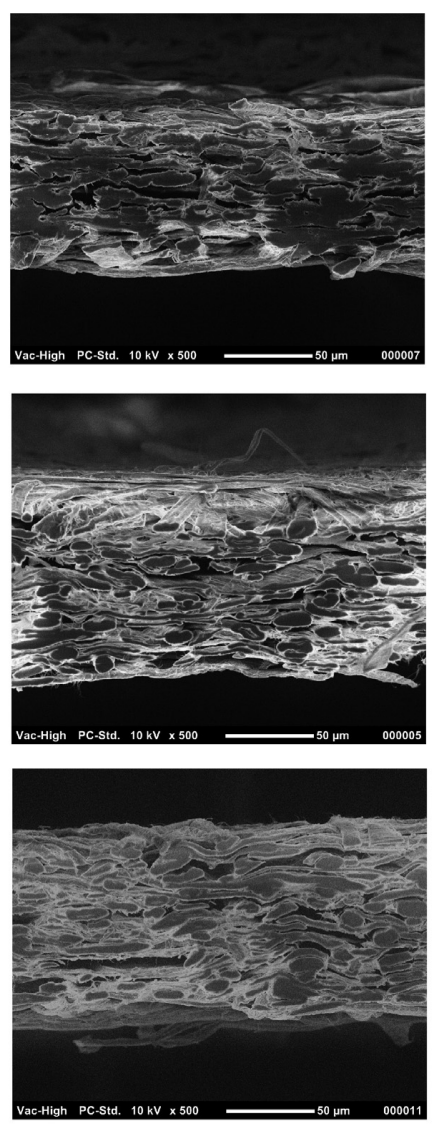

Fig. 9 SEM observations of cross section of the recycled handsheets. 
することなく良好なサイズ性を示し，特にR5におい てさらにサイズ性を向上させることが明らかとなっ た. 低密度調整剂 B の場合は,リサイクルパルプに おいてもサイズ性を示さなかった.

3.リサイクル回数が増加すると, シートの細孔容積は 増加する傾向にあり，低密度調整剂を併用添加した 場合，さらに増加することが認められた。 また，リ サイクル回数の増加とともに紙厚向上効果が大きく なることが SEM 写真によって確認された.

4. いずれの場合も, リサイクル回数を増加するとシー トの細孔直径ピークは最初の $4 \sim 8 \mu \mathrm{m}$ 付近から 2 つに 分離し, R5 になると主要なピークは $10 \mu \mathrm{m}$ 付近に現 れた。また、リサイクル処理によるシート細孔容積 の増加は主に $10 \mu \mathrm{m}$ 領域細孔の増加によるもので, 低 密度調整剤添加リサイクルシートの細孔容積の増加 は主に 4〜 $8 \mu \mathrm{m}$ 領域の細孔の増加によるものであるこ とが明らかとなった。

以上の結果から, パルプ原料への古紙配合率が高い場 合でも低密度調整剤を添加することによって同じ紙厚を 維持しながら原料削減に結びつくことができると判断し た。

\section{5. 謝 辞}

本研究は, 中央高校基本科研業務費専項資金 [2572014CB 05]；中国博士後科学基金[2013M541331］；中国教育部留 学回国人員科研啓動基金の助成を受けたものである.

\section{文 献}

1. K. Asakura, A. Isogai, Nordic Pulp and Paper Journal, 18 (2), 188-193 (2003).

2. H. Jin, T. Okayama, Sen'i Gakkaishi, 65 (5), 139-145 (2009).

3. H. Takahashi, Japanese Journal of Paper Technology, $\mathbf{4 3}$ (7), 14-17 (2000).

4. N. Sone, T. Matsushima and M. Kawamura, Japan Tappi Journal, 59 (9), 60-68 (2005).

5. JIS P 8122 : "Test method for Stöckigt sizing degree of paper”, JSA (2000).

6. T. Yano, H. Ohtani, S. Tsuge, T. Obokata, Analyst, 117 : 849-852 (1992).

7. H. Jin, T. Okayama, R. Arai, H. Ohtani, Journal of Wood and Science, 57 (1), 34-39 (2011).

8. Japan TAPPI Pulp and Paper Testing Methods, No. 48 (2000)

9. D. H. Page, TAPPI, 52 (4), 674-681 (1969).

10. H. Cildir and P. Howarth, Paper Technology, 13 (5), 333335 (1972).

11. K. Murakami, "Porous Structure of Paper and Estimation", in "Science of Papermaking", R. Oye, M. Usuda, and T. Kadoya, Eds, Chugaisangyo-chosakai, Tokyo, p. 211-241 (1982). 